\title{
Osteogenic potential of osteoblasts from neonatal rats born to mothers treated with caffeine throughout pregnancy
}

\author{
Amanda Maria Sena Reis ${ }^{1}$, Lorena Gabriela Rocha Ribeiro', Natália de Melo Ocarino ${ }^{1}$, Alfredo Miranda Goes² \\ and Rogéria Serakides ${ }^{1 *}$
}

\begin{abstract}
Background: Caffeine is an active alkaloid that can cause damage to bones in formation during prenatal life into adulthood. This compound can pass across the placenta and into the mother's milk, causing a reduction in bone formation, growth and mass. The objective of this study was to examine the osteogenic potential of osteoblasts extracted from neonatal rats born to mothers treated with caffeine throughout pregnancy.

Methods: Twenty-four adult Wistar rats were randomly divided into four groups, consisting of one control group and three groups that were treated with 25,50 , or $100 \mathrm{mg} / \mathrm{kg}$ of caffeine by an oral-gastric probe throughout the duration of the experimental period (pregnancy). At birth, three puppies from each dam in each group were euthanized, and osteoblasts were extracted from the calvaria of these pups for in vitro testing.

Results: The osteoblasts extracted from the pups of rats that received $50 \mathrm{mg} / \mathrm{kg}$ caffeine during pregnancy exhibited increased expression of osteocalcin, osteopontin, sialoprotein, runx-2, alkaline phosphatase and type I collagen transcripts, resulting in increased synthesis of mineralization nodules.

Conclusions: Neonates from rats treated with $50 \mathrm{mg} / \mathrm{kg}$ caffeine during pregnancy contained osteoblasts with a higher osteogenic potential characterized by increased expression of osteocalcin, osteopontin, sialoprotein, runx-2, alkaline phosphatase and type I collagen and increased synthesis of mineralization nodules.
\end{abstract}

Keywords: Osteoblasts, Caffeine, Neonate, Osteogenic differentiation, Rat

\section{Background}

Caffeine is a pharmacologically active xanthine (1,3,7-trimethylxanthine) that is present in coffees, teas, soft drinks, food, and drugs [1].

Despite the beneficial effects of caffeine on the central nervous system and the respiratory system, characterized by reduced fatigue and bronchodilation, respectively, the adverse effects of caffeine on the body are more widely documented. Caffeine is known to cause insomnia and anxiety as well as increased blood pressure and pulse. In addition, caffeine is considered a risk factor for osteoporosis and periodontal disease and a causative agent of

\footnotetext{
* Correspondence: serakidesufmg@gmail.com

${ }^{1}$ Núcleo de Células Tronco e Terapia Celular Animal (NCT-TCA) da Escola de Veterinária da Universidade Federal de Minas Gerais, Av. Antônio Carlos 6627, Caixa Postal 567, campus Pampulha da UFMG, CEP 30123-970, Belo Horizonte, MG, Brazil

Full list of author information is available at the end of the article
}

fetal malformations, reductions in body weight, reduced length of long bones and reduced length of vertebrae in newborns [1-7].

Caffeine crosses the placenta leading to substantial amounts in amniotic fluid, umbilical cord blood, newborn plasma and newborn urine and is also carried by the mother's milk in both mice and humans [8-11]. Pregnant women in the third trimester of pregnancy with low caffeine consumption had mean serum levels of caffeine in their umbilical cord blood of $0.48 \mu \mathrm{g} / \mathrm{ml}$ ( 0 to $10.49 \mu \mathrm{g} / \mathrm{ml}$ ). Pregnant women with caffeine intake greater than $300 \mathrm{mg} /$ day averaged $2.1 \mu \mathrm{g} / \mathrm{ml}$ of caffeine in their cord blood [9]. Even in humans, maternal ingestion of 36-335 mg of caffeine has been shown to be transmitted in the milk, which contained between 2.09 to $7.17 \mu \mathrm{g} / \mathrm{ml}$ caffeine [11]. Previous studies have shown that caffeine causes changes in the bones of fetuses 
and young rats. In rat fetuses born to mothers treated with high doses of caffeine, teratogenic changes such as cleft palate, limb malformations, and ectrodactyly [12-14] have been observed, as well as reduced bone mass [15] and reduced bone mineral content [4]. In the offspring of rats treated with caffeine at doses of 25,50 and $100 \mathrm{mg} / \mathrm{kg}$, osteopenia in the long bones and vertebrae was observed [15]. High doses of caffeine inhibit the endochondral bone growth of offspring when administered to rats during pregnancy and lactation. The effects of caffeine are more damaging to cartilage growth in newborns than to pups at weaning [15]. In humans, caffeine intake above $540 \mathrm{mg} /$ day during pregnancy is associated with decreased weight and fetal growth, and combining caffeine intake with smoking and alcohol consumption may further increase risk [16,17].

The mechanism that underlies the changes caused by caffeine, especially in the bones, requires further study. The effects of caffeine on bone metabolism are controversial. Some studies suggest that the consumption of caffeine has been associated with low bone mass and increased fracture risk and that caffeine directly enhances differentiation and maturation of osteoclasts $[18,19]$.

Additionally, it has been postulated that one mechanism by which caffeine alters bone formation and growth is by affecting mesenchymal stem cells and osteoblasts [20,21]. In vitro studies have concluded that caffeine can potentially harm osteoblasts, causing a reduction in viability and synthetic activity [20-23]. The dosage of caffeine can influence the osteogenic differentiation of mesenchymal stem cells [24]. Low doses of caffeine $(0.1 \mathrm{mM})$ in culture medium can increase the mineralization, alkaline phosphatase activity and differentiation genes such as osteocalcin, osteoprotegerin, and Runx-2, whereas higher doses $(\geq 0.3 \mathrm{mM})$ can suppress differentiation [24]. However, little is known about the effects, associated factors and molecular mechanisms of caffeine action during skeletogenesis. Most previous studies that have addressed this issue have investigated the effects of adding caffeine to cultured mesenchymal stem cells and osteoblasts [20-23]. This, however, is the first study to examine the osteogenic potential of osteoblasts extracted from neonatal rats born to mothers treated with caffeine throughout pregnancy.

The osteogenic potential of the cells was evaluated using parameters such as alkaline phosphatase activity; collagen synthesis; gene expression of Runx-2, collagenous proteins and non-collagenous proteins (osteocalcin, osteopontin, sialoprotein); and the synthesis and mineralization of the extracellular matrix. Runx-2 regulates collagenous and non-collagenous protein factors that play a key role in the various stages of differentiation in the extracellular matrix [25-29], while alkaline phosphatase is an early marker of osteogenic differentiation [30,31]; these factors are thus important to evaluate.
Therefore, with the aim of elucidating the mechanism of action of caffeine in osteoblasts, this study analyzed the effects of caffeine on the synthetic activity of cells extracted from the calvaria of newborn rats whose mothers received different doses of caffeine during pregnancy.

\section{Methods}

\section{Animals and study design}

Twenty-four two-month-old female Wistar rats were used in this study. The animals were housed six per cage by experimental group in a 12-h light/dark cycle. They were fed commercial rat chow containing $22 \%$ crude protein, $1.4 \%$ calcium and $0.6 \%$ phosphorus. Food and water were provided ad libitum to all animals. All experimental procedures were approved by the Institutional Ethics Committee in Animal Experimentation at Universidade Federal de Minas Gerais (UFMG) (protocol no. 177/2010).

After a 30-day adaptation period, the rats were randomly divided into four groups, consisting of three groups that were treated with different doses of caffeine and a control group. The treated groups (6 animals/ group) received daily caffeine (Sigma Aldrich, St. Louis, MO, USA) diluted in $5 \mathrm{~mL}$ of distilled water at doses of 25,50 or $100 \mathrm{mg} / \mathrm{Kg}$. The doses of caffeine used in this study were chosen based on previously observed effects on endochondral ossification in the offspring of rats treated with caffeine [15].

The doses were administered by an oral-gastric probe at the same time each day over the course of the experimental period. As a placebo, the control group received $5 \mathrm{~mL}$ of distilled water daily by an oral-gastric probe. The females were subjected to vaginal cytology to monitor the estrous cycle [32]. The female rats that were in estrus and proestrus were kept in plastic cages with adult male rats for $12 \mathrm{~h}$. After this period, vaginal smears were obtained daily to detect spermatozoa. Copulation was confirmed by the presence of spermatozoa in the vaginal cytology samples, and the day of copulation was considered Day 0 of gestation. After copulation, the females were kept individually in plastic cages. The animals in the treated and control groups continued to receive caffeine or water, respectively, by an oral-gastric probe throughout the duration of the experimental period (pregnancy).

At birth, three pups from each dam in each experimental group were euthanized, and osteoblasts were extracted from the calvaria of these pups. The cells were pooled to obtain a cell suspension for in vitro tests. The means and standard deviations were determined from six replicates for each experimental group.

\section{Harvest and culture of osteoblasts from calvaria of newborn pups}

Calvarial osteoblast cultures were established as described previously [26,33]. Briefly, 2 day-old neonatal Wistar rats 
were removed from their cages, and their heads were cut off and immersed in phosphate-buffered saline (PBS) (Synth, São Paulo, SP, Brazil). The calvaria were then dissected out and processed for cell isolation and culture. The calvaria were fragmented and incubated for 15 min with $1 \%$ trypsin (Gibco, Grand Island, NY, USA) and then for $60 \mathrm{~min}$ at $37^{\circ} \mathrm{C}$ in $\mathrm{PBS}$ with $0.25 \%$ collagenase (Type I; Sigma, St Louis, MO, USA). The cells that dissociated from the fragments of calvaria were washed several times in PBS, suspended in DMEM medium (Gibco, Grand Island, NY, USA) supplemented with $10 \%$ fetal bovine serum (Gibco, Grand Island, NY, USA) and antibiotics $(60 \mu \mathrm{g} / \mathrm{L}$ gentamicin, $25 \mu \mathrm{g} / \mathrm{L}$ amphotericin $\mathrm{B}, 100 \mathrm{U} / \mathrm{mL}$ penicillin and $100 \mu \mathrm{g} / \mathrm{mL}$ streptomycin; Gibco, Grand Island, NY, USA), and collected in a $75-\mathrm{cm}^{2}$ culture flask containing $10 \mathrm{~mL}$ of culture medium. The cells were grown at $37^{\circ} \mathrm{C}$ in a $5 \% \mathrm{CO}_{2}$ atmosphere for 3 days. The non-adherent cell population was removed, and the adherent layer was washed once with fresh medium. The culture medium was changed twice a week during culturing.

\section{Culture of osteoblasts in osteogenic differentiation medium}

After the fourth passage, the adherent cells were harvested by treatment with trypsin. They were then counted and plated in 6- and 24-well culture plates $\left(1 \times 10^{4}\right.$ cells $\left./ \mathrm{cm}^{2}\right)$. The cells were cultured in osteogenic medium, which consists of DMEM (Gibco, Grand Island, NY, USA) supplemented with $10 \%$ fetal bovine serum (Gibco, Grand Island, NY, USA), antibiotics ( $60 \mu \mathrm{g} / \mathrm{L}$ gentamicin, $25 \mu \mathrm{g} / \mathrm{L}$ amphotericin B, $100 \mathrm{U} / \mathrm{mL}$ penicillin, $100 \mu \mathrm{g} / \mathrm{mL}$ streptomycin; Gibco, Grand Island, NY, USA), $10 \mathrm{mM} \beta$-glycerophosphate (Sigma, St. Louis, MO, USA), $50 \mu \mathrm{g} / \mathrm{mL}$ ascorbic acid (Merck, Germany) and $10 \mathrm{nM}$ dexamethasone (Sigma-Aldrich, St Louis, MO, USA) [26,33]. The cells were grown at $37^{\circ} \mathrm{C}$ in a $5 \% \mathrm{CO}_{2}$ atmosphere. The cells were grown for 7, 14 and 21 days to assess the conversion of MTT into formazan crystals, collagen synthesis, alkaline phosphatase activity, production of mineralized nodules and the expression of osteocalcin, osteopontin, bone sialoprotein, alkaline phosphatase and type I collagen via $\mathrm{qRT}$-PCR.

\section{MTT reduction assay}

MTT conversion is a measure of cell viability. Briefly, the cells were incubated with MTT (3-(4,5-dimethylthiazol-2-yl)-2,5 diphenyltetrazolium bromide) (Invitrogen, Eugene, Oregon, USA) for $2 \mathrm{~h}$ at $37^{\circ} \mathrm{C}$. After incubation with MTT, the cells were treated for $12 \mathrm{~h}$ with a solubilization solution (sodium dodecyl sulfate in $10 \% \mathrm{HCl}$ ) (Synth, São Paulo, SP, Brazil), and the absorbance of the solubilized MTT formazan product was measured at $595 \mathrm{~nm}$ using a microtiter plate reader [23,24]. The means and standard deviations were determined from six replicates for each experimental group.

\section{Alkaline phosphatase activity}

At the end of each period (7, 14 and 21 days), the osteoblasts from the newborn pups of all groups were cultured in 24-well plates and washed with 0.15 M PBS. Two hundred microliters of BCIP/NBT solution $(1 \mathrm{~mL}$ of alkaline phosphatase buffer, $4.4 \mu \mathrm{L}$ of NBT \{nitro-blue tetrazolium chloride\} and $3.3 \mu \mathrm{L}$ of BCIP \{5-bromo-4chloro-3'-indolylphosphate p-toluidine salt $\}$ ) (Invitrogen, Camarilho, CA, USA) were added to each well. The plates were incubated for $2 \mathrm{~h}$ at $37^{\circ} \mathrm{C}$. After incubation with $\mathrm{BCIP} / \mathrm{NBT}$, the cells were treated with a solubilization solution (sodium dodecyl sulfate in $10 \% \mathrm{HCl}$ ) (Synth, São Paulo, SP, Brazil), and the absorbance of the solubilized BCIP/NBT was measured at $595 \mathrm{~nm}$ using a microtiter plate reader $[34,35]$. The means and standard deviations were determined from six replicates for each experimental group.

\section{Collagen synthesis}

At the end of each period (7, 14 and 21 days), the osteoblasts of newborn pups of all groups were cultured in 6-well plates and washed with 0.15 M PBS (Synth, São Paulo, SP, Brazil). Four milliliters of Bouin solution (Merk, Germany) was added to each well. The samples were incubated for $2 \mathrm{~h}$ at $37^{\circ} \mathrm{C}$ and subsequently moved to a refrigerator. The following day, the cells were washed, dried and incubated in Sirius Red (Reagent, Rio de Janeiro, RJ, Brazil) $(2 \mathrm{~mL})$ for $30 \mathrm{~min}$. After the dye was removed, the cells were washed with $\mathrm{HCl}$ (Synth, São Paulo, SP, Brazil) and $\mathrm{NaOH}$ (Synth, São Paulo, SP, Brazil) and incubated for $30 \mathrm{~min}$. Subsequently, $100 \mu \mathrm{L}$ from each well was transferred to a 96-well plate, and the absorbance of each sample at $540 \mathrm{~nm}$ was analyzed using a plate reader [33]. The means and standard deviations were determined from six replicates for each experimental group.

\section{Mineralization assay}

The cells were cultured in six-well culture plates with $22 \times$ $22 \mathrm{~mm}$ coverslips. The cells were washed in PBS (Synth, São Paulo, SP, Brazil), fixed in 4\% paraformaldehyde (Synth, São Paulo, SP, Brazil) and rinsed with deionized water. After the addition of a $5 \%$ silver nitrate solution (Synth, São Paulo, SP, Brazil), the wells were exposed to light for $2 \mathrm{~h}$. The plates were rinsed with deionized water, and the residual silver nitrate was neutralized by $5 \%$ sodium thiosulfate (Synth, São Paulo, SP, Brazil); after neutralization, the calcium deposits were visible by dark brown staining. The percentage of mineralized nodules was assessed by light microscopy. The mean percentage of nodules was quantified at 21 days of osteogenic differentiation; 50 fields were counted using a $10 \times$ objective and a 121-point graticule superimposed on the histological sections [36]. The means and standard deviations were determined from six replicates for each experimental group. 


\section{Real-time quantitative PCR (qRT-PCR)}

Total mRNA was extracted using TRIzol reagent (Ambion, Carlsbad, CA, USA) according to the manufacturer's instructions. Osteoblasts from each experimental group cultured in osteogenic medium for 7, 14, or 21 days were assayed for osteocalcin, osteopontin, bone sialoprotein, alkaline phosphatase and type I collagen expression. Osteoblasts cultured in osteogenic medium for 21 days were assayed for runx-2 expression. The means and standard deviations were determined from four replicates for each experimental group. One microgram of RNA was subjected to cDNA synthesis using a SuperScript III Platinum Two-Step qPCR kit with SYBR Green (Invitrogen, Carlsbad, CA, USA). The qRT-PCR reactions were conducted in a Smart Cycler II thermocycler (Cepheid, Carpinteria, CA, USA). The one-step qRT-PCR amplification started with reverse transcription for $120 \mathrm{~s}$ at $50^{\circ} \mathrm{C}$, followed by PCR with the following parameters: 45 cycles of $15 \mathrm{~s}$ at $95^{\circ} \mathrm{C}$ and $30 \mathrm{~s}$ at $60^{\circ} \mathrm{C}$. At the end of each run, the fluorescence data were analyzed to obtain CT values. Gene expression was calculated using the $2^{-\Delta \Delta C t}$ method, where the values from samples were averaged and normalized to GAPDH CT values. The specific primers used are shown in Table 1 . The results for each group were compared quantitatively after normalization to the expression of Rattus norvegicus GAPDH.

\section{Statistical analysis}

The means and standard deviations were determined for each variable. We performed ANOVA and compared the

Table 1 List of genes and oligonucleotide sequences of the primers used for real-time RT-PCR

\begin{tabular}{lll}
\hline Gene & Primers: 5'-3' & $\begin{array}{l}\text { Access } \\
\text { number }\end{array}$ \\
\hline GAPDH & Foward: CAACTCCCTCAAGATTGTCAGCAA & NM 002046 \\
& Reverse: GGCATGGACTGTGGTCATGA & \\
Type 1 & Foward: ACGTCCTGGTGAAGTTGGTC & NM 000088 \\
collagen & Reverse: CAGGGAAGCCTCTTCTCCT & \\
Osteocalcin & Foward: CATCTATGGCACCACCGTTT & NM 013414.1 \\
Bone & Reverse: AGAGAGAGGGAACAGGGAGG & \\
sialoprotein & Foward: TGTCCTTCTGAACGGGTTC & NM 012587.2 \\
Osteopontin & Fowerse: CTTCCCCATACTCAACCGTG & \\
& Reverse: TCAGTCCATAAGCCAAGCTATCA & \\
Alkaline & Foward: CTAGTTCCTGGGAGATGGTA & AC_000073.1 \\
Phosphatase & Reverse: GTGTTGTACGTCTTGGAGAGA & \\
Runx-2 & Forward: GCGTCAACACCATCATTCTG & NM_004348 \\
& Reverse: CAGACCAGCAGCACTCCATC & \\
\hline
\end{tabular}

means using an SNK test. Differences were considered to be significant at $\mathrm{p}<0.05$ [37].

\section{Results}

\section{Conversion of MTT to formazan crystals}

The conversion of MTT into formazan crystals varied with the dose of caffeine administered to the mother and the culture period. At 7 days, the groups treated with 25 and $50 \mathrm{mg} / \mathrm{kg}$ caffeine showed less conversion of MTT into formazan crystals than the control group. However, at 14 days, osteoblasts from all the caffeinetreated groups $(25,50$ and $100 \mathrm{mg} / \mathrm{kg}$ ) showed decreased conversion of MTT into formazan crystals compared with the controls $(\mathrm{p} \leq 0.05)$. At 21 days, the groups treated with 25 and $50 \mathrm{mg} / \mathrm{kg}$ caffeine showed no difference in the conversion of MTT to formazan crystals relative to the control group; however, the $100 \mathrm{mg} / \mathrm{kg}$ group showed a significant increase compared with the control group (Figure 1).

\section{Alkaline phosphatase activity and synthesis of collagen}

At 7 days of culture, the groups treated with 50 and $100 \mathrm{mg} / \mathrm{kg}$ caffeine showed significantly higher alkaline phosphatase activity than the controls. At 14 days, the osteoblasts isolated from the 25 and $50 \mathrm{mg} / \mathrm{kg}$ groups showed significantly higher alkaline phosphatase activity than the control group. At 21 days of culture, only the group treated with $50 \mathrm{mg} / \mathrm{kg}$ caffeine maintained significantly higher alkaline phosphatase activity over than of the control group (Figure 2a).

At 7 days of culture, the groups treated with 50 and $100 \mathrm{mg} / \mathrm{kg}$ caffeine showed significantly higher collagen synthesis than the control group. At 14 days of culture, all three caffeine-treated groups showed significantly higher collagen synthesis than the controls. However, at 21 days of culture, only the osteoblasts cultured from the $50 \mathrm{mg} / \mathrm{kg}$ group maintained this increased collagen synthesis $(\mathrm{p} \leq 0.05)$ (Figure $2 \mathrm{~b})$.

\section{Synthesis of mineralization nodules}

At 7 and 14 days of culture, there was variation among the cultures in the percentages of mineralization nodules, but there were no significant differences between the groups. However, at 21 days, the amount of variation was reduced, as indicated by a decrease in the standard deviations. The osteoblast cultures from the $50 \mathrm{mg} / \mathrm{kg}$ caffeine-treated group showed a significant increase in the percentage of mineralization nodules compared with the control group (Figure 3a). Furthermore, the calcium content of the nodules, as reflected by black staining, was higher in the group treated with $50 \mathrm{mg} / \mathrm{kg}$ caffeine than in the other groups (Figure 3b). 


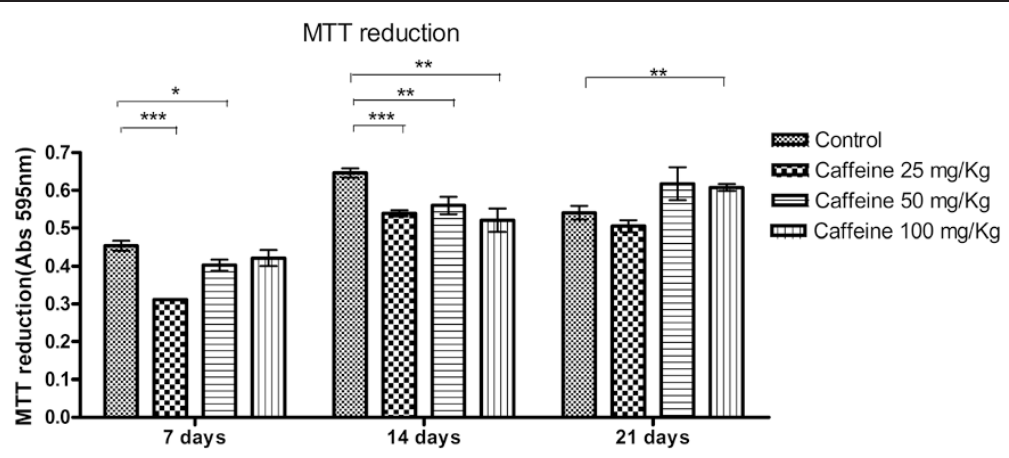

Figure 1 Cell viability (mean \pm standard deviation) characterized by conversion of MTT into formazan crystals by calvarial osteoblasts taken from newborn control rats or those exposed to various concentrations of caffeine $(25,50,100 \mathrm{mg} / \mathrm{Kg})$ during pregnancy and subsequently cultured in osteogenic differentiation medium for $\mathbf{7 , 1 4}$ or $\mathbf{2 1}$ days. ${ }^{*} p<0.05,{ }^{* *} p<0.01$, ${ }^{* * *} p<0.001$.

\section{Expression of osteogenic genes}

At 7 days, the group treated with $25 \mathrm{mg} / \mathrm{kg}$ caffeine showed a significant increase in osteocalcin expression, while the $100 \mathrm{mg} / \mathrm{kg}$ group showed a significant reduction in the expression of this gene. However, at 14 and 21 days of culture, the osteoblasts of the $50 \mathrm{mg} / \mathrm{kg}$ caffeine-treated group showed a significant increase in the expression of osteocalcin compared with the control group (Figure 4a). Osteopontin expression was significant higher in all of the caffeine-treated groups $(25,50$ and $100 \mathrm{mg} / \mathrm{kg})$ at 7 days of culture than in the control group. However, at 14 and 21 days of culture, only the osteoblasts from the 25 and
$50 \mathrm{mg} / \mathrm{kg}$ groups showed significantly higher expression of osteopontin (Figure 4b). At 7 days, sialoprotein expression was significantly increased in the $25 \mathrm{mg} / \mathrm{kg}$ group, but significantly decreased in the $100 \mathrm{mg} / \mathrm{kg}$ group. At 14 days, osteoblasts from the groups treated with 25 and $50 \mathrm{mg} / \mathrm{kg}$ caffeine showed significantly higher expression of sialoprotein than the control group. However, at 21 days, only osteoblasts from the group treated with $50 \mathrm{mg} / \mathrm{kg}$ caffeine maintained significantly higher sialoprotein expression than the controls (Figure 5a).

At 21 days of culture, only the group treated with $50 \mathrm{mg} / \mathrm{kg}$ caffeine showed a significant increase in runx-2
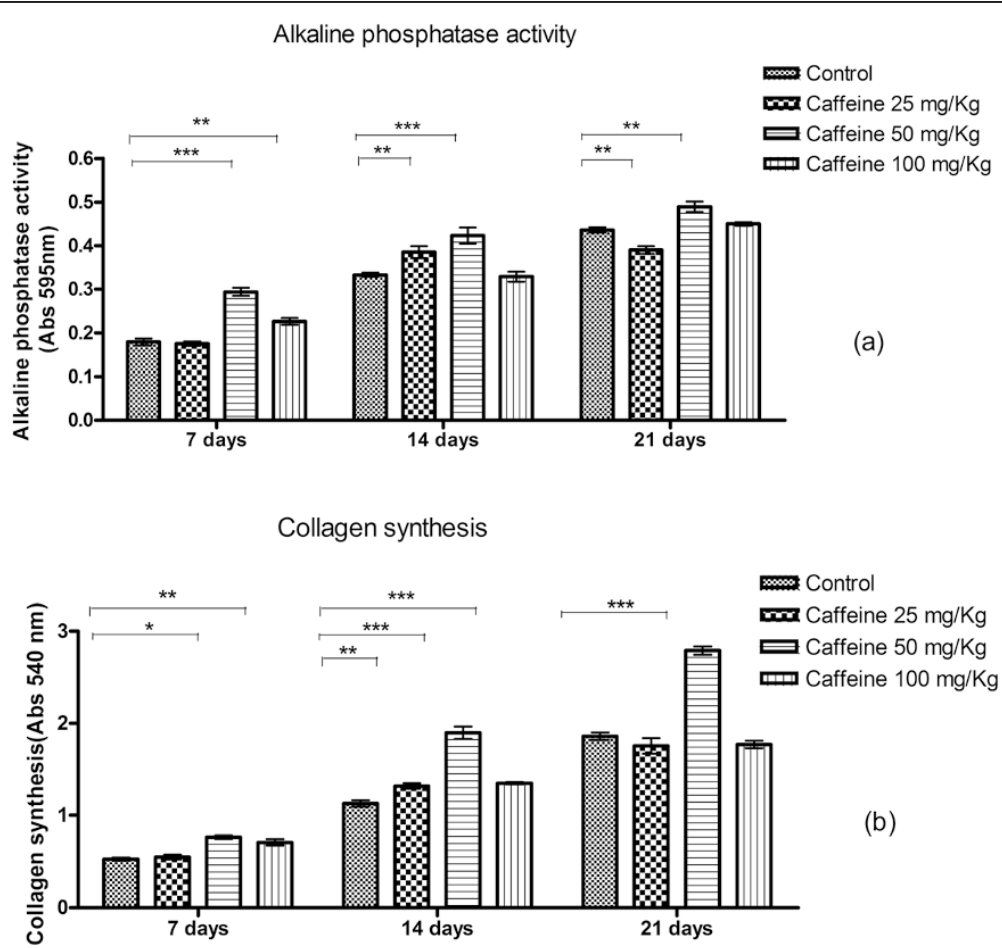

Figure 2 Alkaline phosphatase activity (a) and synthesis of collagen (b) (mean \pm standard deviation) in calvarial osteoblasts taken from newborn control rats or those exposed to various concentrations of caffeine $(25,50,100 \mathrm{mg} / \mathrm{Kg})$ during pregnancy and subsequently cultured in osteogenic differentiation medium for 7,14 or 21 days. ${ }^{*} p<0.05,{ }^{* *} p<0.01,{ }^{* * *} p<0.001$. 
(a) Percentage of mineralized nodules 21 day

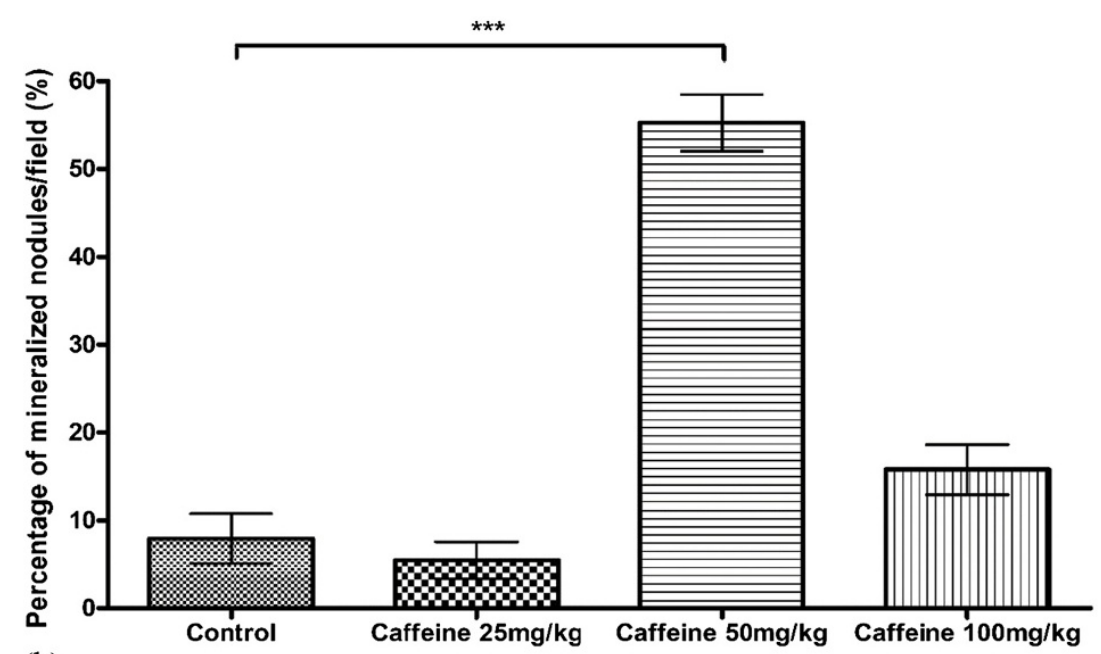

(b)

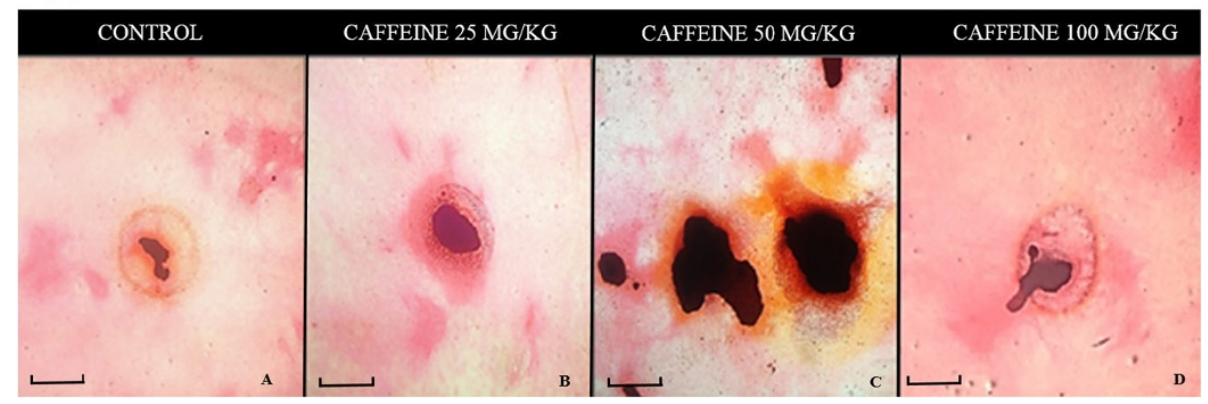

Figure 3 Percentage of mineralization nodules/field (mean \pm standard deviation) (a) and Von Kossa staining (b) of calvarial osteoblasts taken from newborn control rats and those exposed to various concentrations of caffeine $(25,50,100 \mathrm{mg} / \mathrm{Kg})$ during pregnancy and subsequently cultured in osteogenic differentiation medium for 21 days. ${ }^{* *} p<0.001$. Bar $=58.5 \mu \mathrm{m}$.

expression compared with controls (Figure 5b). Cells from all other experimental periods and doses exhibited no significant differences in runx-2 expression compared with the control group.

At 7 and 14 days of culture, alkaline phosphatase expression was significantly increased compared with controls only in the group treated with $50 \mathrm{mg} / \mathrm{kg}$ caffeine. At 21 days, there were no differences in alkaline phosphatase expression between the groups (Figure 6a). At 7 and 14 days, the group treated with $25 \mathrm{mg} / \mathrm{kg}$ caffeine had lower type I collagen expression than the controls, and the group treated with $50 \mathrm{mg} / \mathrm{kg}$ caffeine had higher expression. At 21 days of culture, there were no significant differences in type I collagen expression between the groups (Figure 6b).

\section{Discussion}

Previous studies with cultured osteoblasts showed that caffeine can be harmful [20-23] and may be considered a risk factor for osteoporosis [18,29] and a causative agent of fetal malformations $[5,12,14,15]$. The mechanisms that underlie these changes in bone tissue remain poorly understood $[5,12,15,38-40]$. To the best of our knowledge, this work describes for the first time the effects of caffeine administration during pregnancy on the osteogenic potential of osteoblasts derived from pups.

The majority of cells extracted from calvaria are osteoblasts, although the derived cell population also includes pre-osteoblasts [41]. In the present study, these cells were evaluated after passaging three times in osteogenic medium to stimulate the differentiation of all extracted cells. To characterize and compare the osteogenic potential of the osteoblasts extracted from each experimental group, several parameters were evaluated: alkaline phosphatase activity, collagen synthesis, and the synthesis and mineralization of the extracellular matrix. During the process of cell differentiation, osteoblasts produce the bone extracellular matrix, which is composed of collagenous and non-collagenous proteins. Many of these proteins play a key role in the various stages of differentiation 

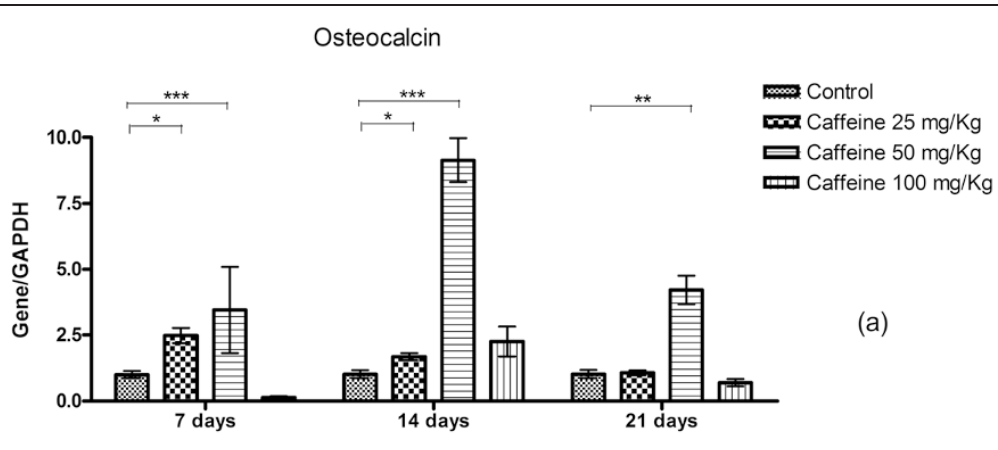

(a)

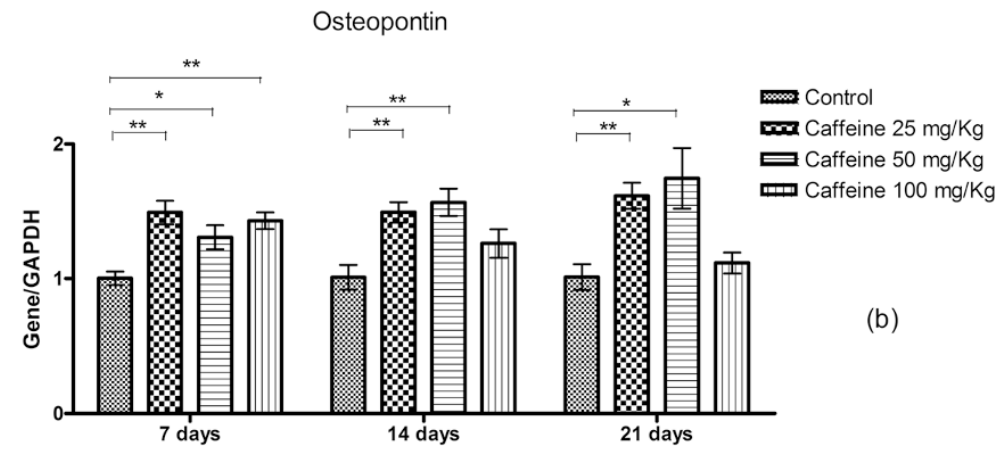

Figure 4 The relative quantification (mean \pm standard deviation) of osteocalcin (a) and osteopontin (b) transcripts as measured by real-time RT-PCR in calvarial osteoblasts taken from newborn control rats and those exposed to various concentrations of caffeine during pregnancy and subsequently cultured in osteogenic differentiation medium for $\mathbf{7 , 1 4}$ or 21 days. ${ }^{*} p<0.05,{ }^{* *} p<0.01,{ }^{* * *} p<0.001$.

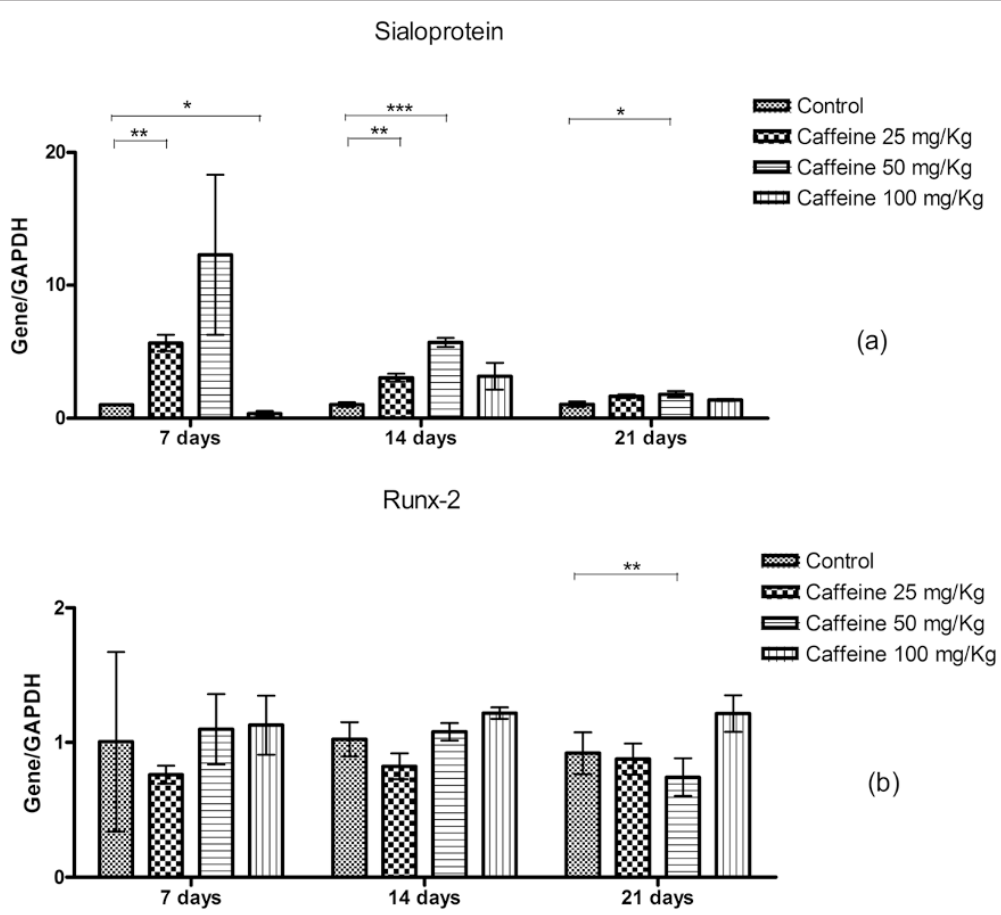

Figure 5 The relative quantification (mean \pm standard deviation) of sialoprotein (a) and runx-2 (b) transcripts as measured by real-time RT-PCR in calvarial osteoblasts taken from newborn control rats and those exposed to various concentrations of caffeine $(25,50,100 \mathrm{mg} / \mathrm{Kg})$ during pregnancy and subsequently cultured in osteogenic differentiation medium for 7,14 or 21 days. ${ }^{*} p<0.05,{ }^{* *} p<0.01,{ }^{* * *} p<0.001$. 

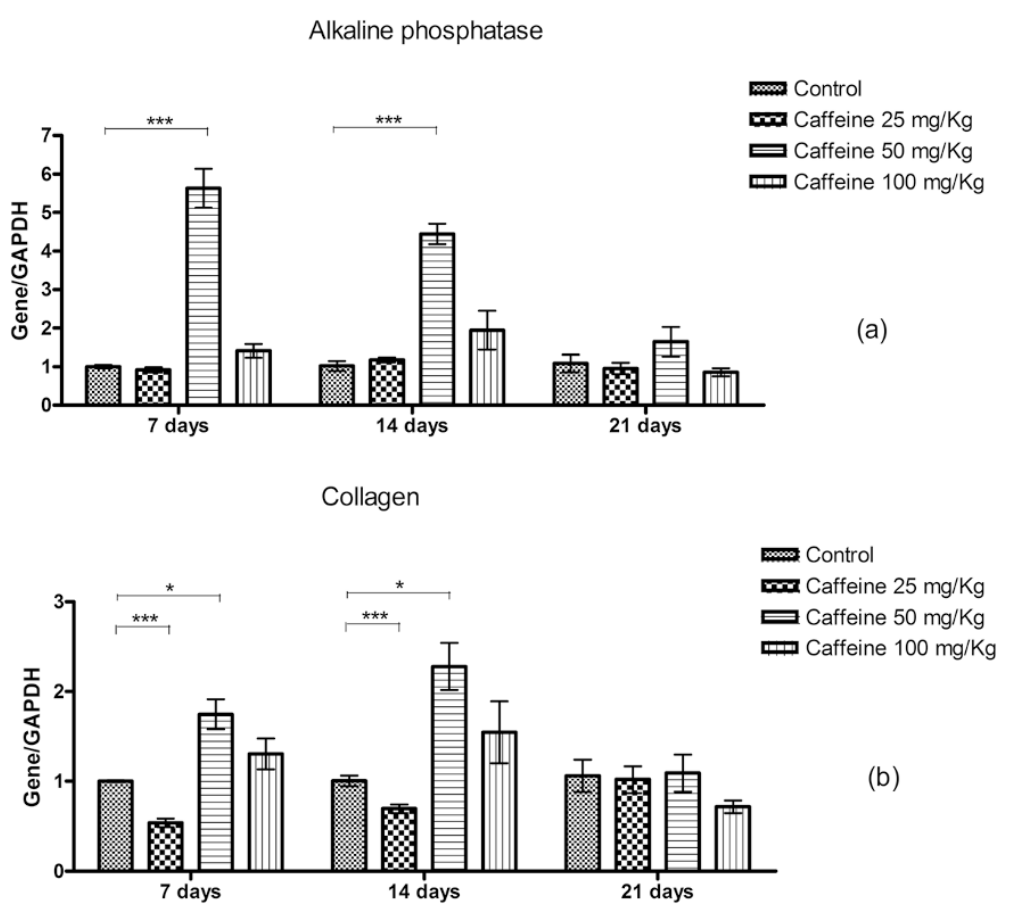

Figure 6 The relative quantification (mean \pm standard deviation) of alkaline phosphatase (a) and type I collagen transcripts (b) as measured by real-time RT-PCR in calvarial osteoblasts from newborn control rats and those exposed to various concentrations of caffeine $(25,50,100 \mathrm{mg} / \mathrm{Kg})$ during pregnancy and subsequently cultured in osteogenic differentiation medium for 7,14 or 21 days. ${ }^{*} p<0.05,{ }^{* *} p<0.01,{ }^{* * *} p<0.001$.

and mineralization of the bone matrix; here we highlight osteocalcin, sialoprotein and osteopontin $[20,41,42]$, which were evaluated in this study.

Our results were surprising and interesting. In contrast with previously reported results from in vitro studies $[20,21]$, we found that caffeine, predominantly at $50 \mathrm{mg} /$ $\mathrm{kg}$, increased the osteogenic potential of osteoblasts, as characterized by increased alkaline phosphatase activity, collagen synthesis, mineralization of nodules and expression of osteogenic genes including osteocalcin, osteopontin, Runx-2, sialoprotein, alkaline phosphatase and type I collagen.

The methodology used and the results obtained in this study were different from those reported by other researchers; previous studies showed that the viability and activity of osteoblasts decreased significantly when exposed to increasing doses of caffeine $(0.4,0,5,1.0$ and $10 \mathrm{mM}$ ) in the culture medium [20-23]. The most important aspect of our method of caffeine administration is that the drug was not added to the culture medium as in most of the previous studies; we administered caffeine to mothers during pregnancy, and the drug passed through the placenta to the fetus. The doses of caffeine used in this study were chosen based on previously observed effects on endochondral ossification in the offspring of rats treated with caffeine [15]. When added directly to the culture medium, caffeine inactivates cell survival signaling and promotes programmed cell death by a mitochondria-dependent cascade; cell death thus occurs by apoptosis and necrosis [20-23]. Furthermore, there is decreased expression of genes, enzymes and proteins expressed during osteogenesis, such as Runx-2, alkaline phosphatase, type I collagen, osteocalcin, osteopontin, and histones [21-23,43]. The results obtained with the addition of caffeine to osteoblast cultures demonstrate that in addition to reducing cell viability, caffeine also inhibits the synthesis of the extracellular matrix $[22,23]$.

However, in vitro assays may be different from in vivo and ex vivo assays because the cellular microenvironment of the organism is difficult to reproduce in vitro due to numerous interdependent intrinsic and extrinsic factors. The control of proliferation, differentiation and cell maintenance is carried out by genes, cytokines, developmental and growth factors and cellular interactions [44-46]. Thus, even with our knowledge of the regulation of the cellular microenvironment, it is difficult to develop in vitro models that can simulate drug effects in the body [44-46]. Although in vitro assays with cultured osteoblasts reproduce the cellular sequences that occur before and during the formation of bone matrix in vivo [41], the drugs used in in vitro studies are added directly to the culture medium and not metabolized by the body. This lack of drug metabolism may potentiate the effects of drugs on cells [21,43]. The aim of this study was to 
observe the effects of caffeine on the metabolism of osteoblasts in pups whose mothers were exposed to caffeine during pregnancy, taking into consideration the metabolism of the drug by the mother and its passage to the fetus through the placenta.

At 7 and 14 days, alkaline phosphatase activity and collagen synthesis were significantly higher in the group that received $50 \mathrm{mg} / \mathrm{kg}$ caffeine than in controls, based on both colorimetric assays and RT-PCR. Alkaline phosphatase is an early marker of osteogenic differentiation $[47,48]$; therefore, the increase in alkaline phosphatase suggests an increase in differentiation and early osteogenesis in the treated group compared with the control group. However, the increase in the gene transcript does not necessarily mean that the protein was also increased. In tests of the conversion of MTT into formazan crystals, osteoblasts from rat neonates that received a dose of $50 \mathrm{mg} / \mathrm{kg}$ caffeine showed a lower conversion of MTT into formazan at 7 and 14 days of culture. We cannot infer that these results are due to a reduction in cell viability. We postulate that this observation may be due to an increase in differentiation, as evidenced by collagen synthesis, MTT, and the synthesis of non-collagenous proteins and mineralization nodules, which are discussed below. The MTT assay is a cell viability test; the formation of formazan crystals depends on the mitochondrial activity of viable cells. However, mitochondrial activity also varies with cell maturity, and the decrease in mitochondrial activity during maturation means that differentiated cells frequently show a reduction in formazan crystal formation [49,50]. At caffeine doses of $25 \mathrm{mg} / \mathrm{kg}$ and $50 \mathrm{mg} / \mathrm{kg}$, the osteoblasts showed decreased conversion of MTT into formazan crystals after 7 and 14 days of culture. At 21 days, the group treated with $100 \mathrm{mg} / \mathrm{kg}$ caffeine showed higher conversion of MTT into formazan crystals than the controls. Except for the $50 \mathrm{mg} / \mathrm{kg}$ group, it is difficult to explain the changes observed in the MTT assays of the groups that were treated with caffeine. Because the MTT assay is dependent on mitochondrial activity, more studies should be conducted to study the effects of caffeine on these cellular organelles.

Of the three doses of caffeine studied, the $50 \mathrm{mg} / \mathrm{kg}$ dose resulted in elevated type I collagen and alkaline phosphatase expression, enhanced synthesis and mineralization of nodules and increased expression of non-collagenous proteins such as osteocalcin, collagen, sialoprotein, Runx-2 and osteopontin compared with the control group at the studied time points. These proteins are important indicators of late osteogenic differentiation [41,51-57]. Therefore, it can be inferred that the osteoblasts cultured from the offspring of rats treated with caffeine at a dose of $50 \mathrm{mg} / \mathrm{kg}$ showed increased osteogenic potential in the early and late stages of differentiation. The increased osteogenic potential of osteoblasts in this study should be interpreted with caution, and further studies are needed to understand the relationship between these results and the bone changes observed in vivo. This increase should not necessarily be interpreted as beneficial for bone growth because any imbalance in cellular function, whether an increase or decrease, may impair skeletogenesis. Caffeine binds to adenosine receptors, and modulate several others receptors including glucocorticoid receptors, insulin, estrogen, androgen, vitamin D, cannabinoid, glutamate and adrenergic receptors, all of which are expressed in osteoblasts or osteoprogenitor cells and have important functions during osteoblast differentiation [23,58-72]. However, little is known about the action of caffeine on these receptors or the resultant effects on endochondral bone formation and growth. Therefore, unfortunately, it is too early to determine the implications for humans or to suggest a mechanism of action for the observed increase in osteogenic factors. Numerous factors in the cellular microenvironment could also be responsible for the observed effects, although more studies are needed to identify these factors and elucidate their mechanisms of action.

Although $25 \mathrm{mg} / \mathrm{kg}$ of caffeine also increased the expression of osteocalcin, sialoprotein and osteopontin at two of the time points studied, the synthesis of mineralization nodules was not affected at this dose. This result is likely due to the reduction of collagen expression observed in this group. The formation of mineralization nodules depends on the synthesis of non-collagenous proteins and collagen prior to the mineralization process [41]. A dose of $100 \mathrm{mg} / \mathrm{kg}$ caffeine also promoted changes in the transcript levels of osteocalcin, osteopontin and sialoprotein at 7 days but did not alter the synthesis of mineralization nodules compared with the controls. However, it is important to note that with the exception of the MTT assay at 21 days, the $25 \mathrm{mg} / \mathrm{kg}$ and $100 \mathrm{mg} / \mathrm{kg}$ doses were similar to the controls in all parameters evaluated.

\section{Conclusions}

In conclusion, osteoblasts extracted from the pups of rats that received caffeine at a dose of $50 \mathrm{mg} / \mathrm{kg}$ during pregnancy exhibit increased expression of osteocalcin, osteopontin, sialoprotein, runx-2, alkaline phosphatase, and type I collagen, resulting in increased synthesis of mineralization nodules. Our work presents novel results using methodology not previously performed and demonstrates the need for further studies to better understand the significance of our results and the differences in effects on osteogenic potential when caffeine is administered in vivo or directly to culture media.

\section{Competing interests}

The authors declare that they have no competing interests.

\section{Authors' contributions}

All authors contributed to the data collection and manuscript preparation. AMS, LG, AMG, NM and RS contributed to the cell culture and other in vitro assays. AMS, NM and RS also participated in all statistical analyses and 
interpretation of the data. All authors approved the final version of the manuscript.

\section{Acknowledgements}

This work was supported by grants from the Fundação de Amparo à Pesquisa de Minas Gerais (Fapemig), the Conselho Nacional de Desenvolvimento Científico e Tecnológico (CNPq), the Coordenação de Aperfeiçoamento de Pessoal de Nivel Superior (Capes) and Pró-reitoria de Pesquisa da Universidade Federal de Minas Ferais (PRPQ).

\section{Author details}

'Núcleo de Células Tronco e Terapia Celular Animal (NCT-TCA) da Escola de Veterinária da Universidade Federal de Minas Gerais, Av. Antônio Carlos 6627, Caixa Postal 567, campus Pampulha da UFMG, CEP 30123-970, Belo Horizonte, MG, Brazil. " Laboratório de Imunologia Celular e Biologia Molecular do Departamento de Bioquímica e Imunologia, Instituto de Ciências Biológicas, Universidade Federal de Minas Gerais, Avenida Presidente Antônio Carlos, 6627, CEP: 30.161-970, Belo Horizonte, Minas Gerais, Brazil.

\section{Received: 7 August 2014 Accepted: 15 January 2015}

\section{Published online: 04 February 2015}

\section{References}

1. Dews PB. Caffeine. Ann Nutr. 1982;2:323-41.

2. Smith A. Effects of caffeine on human behavior. Food Chem Toxicol. 2002:40:1243-55.

3. Nawrot P, Jordan S, Eastwood J, Rotstein J, Hugenholtz A, Feeley M. Effects of caffeine on human health. Food Addit Contam. 2003;20:1-30.

4. Fisone G, Borgkvist A, Usiello A. Caffeine as a psychomotor stimulant: mechanism of action. Cell Mol Life Sci. 2004;61:857-72.

5. Nakamoto T, Grant S, Yazdani M. The effects of maternal caffeine intake during pregnancy on mineral contents of fetal rat bone. Res Exp Med. 1989;189:275-80.

6. Narod SA, Santose S, Victora C. Coffee during pregnancy: a reproductive hazard? Am J Obstet Gynecol. 1991;164:1109-14.

7. Mandel HG. Update on caffeine consumption, disposition and action. Food Chem Toxicol. 2002:40:1231-4.

8. Souza RAG, Sichieri R. Consumo de cafeína e prematuridade. Rev Nutr. 2005;18:643-50.

9. Grosso LM, Triche E, Benowitz NL, Bracken MB. Prenatal caffeine assessment: fetal and maternal biomarkers or self reported intake? Ann Epidemiol. 2008;18:172-8

10. Ostrea EM, Mantaring JB, Silvestre MA. Drugs that affect the fetus and newborn infant via the placenta or breast milk. Pediatr Clin N Am. 2004;51:539-79.

11. Berlin Jr CM, Denson HM, Daniel CH, Ward RM. Disposition of dietary caffeine in milk, saliva, and plasma of lactating women. Pediatrics. 1984:73:59-63.

12. Scott Jr WJ. Caffeine-induced limb malformations: description of malformations and quantitation of placental transfer. Teratology. 1983;28:427-35.

13. Collins TFX, Welsh JJ, Black TN, Collins EV. A study of the teratogenic potential of caffeine given by oral intubation to rats. Regul Toxicol Pharmacol. 1981;1:355-78.

14. Collins TF, Welsh JJ, Black TN, Ruggles DI. A study of the teratogenic potential of caffeine ingested in drinking-water. Food Chem Toxicol. 1983;21:763-77.

15. Reis AMS, Batista ACM, Ocarino NM, Serakides R. Effects of caffeine intake in mothers on maternal cortisol levels and offspring endochondral ossification. Actualizaciones En Osteología. 2014;10:20-36.

16. Christian MS, Brent RL. Teratogen update: evaluation of the reproductive and developmental risks of caffeine. Teratology. 2001;64:51-78.

17. Bakker R, Steegers EAP, Obradov A, Raat H, Hofman A, Jaddoe WW. Maternal caffeine intake from coffee and tea, fetal growth, and the risks of adverse birth outcomes: the generation R study. Am J Clin Nutr. 2010;91:1691-8.

18. Liu SH, Chen C, Yang RS, Yen YP, Yang YT, Tsai C. Caffeine enhances osteoclast differentiation from bone marrow hematopoietic cells and reduces bone mineral density in growing rats. J Orthop Res. 2011;29:954-60.

19. Choi J, Choi SY, Lee SY, Lee JY, Kim HS, Lee SY, et al. Caffeine enhances osteoclast differentiation and maturation through p38 MAP kinase/Mitf and DC-STAMP/CtsK and TRAP pathway. Cell Signal. 2013;25:1222-7.
20. Tsuang JSS, Chen LT, Sun SCK, Chen SC. Direct effects of caffeine on osteoblastic cells metabolism: thepossible causal effect of caffeine on the formation of osteoporosis. J Orth Surg Res. 2006;1:1-10.

21. Tassinari MS, Gerstenfeld LC, Stein GS, Lian JB. Effect of caffeine on parameters of osteoblast growth and differentiation of a mineralized extracellular matrix in vitro. Bone Miner Res. 1991;6:1029-36.

22. Rapuri PB, Gallagher JC, Nawaz Z. Caffeine decreases vitamin D receptor protein expression and 1,25(OH)2D3 stimulated alkaline phosphatase activity in human osteoblast cells. J Steroid Biochem Mol Biol. 2007;103:368-71.

23. Lu PZ, Lai CY, Chan WH. Caffeine induces cell death via activation of apoptotic signal and inactivation of survival signal in human osteoblasts. Int J Mol Sci. 2008;9:698-718.

24. Su SJ, Chang KL, Su SH, Yeh YT, Shyu HW, Chen KM. Caffeine regulates osteogenic differentiation and mineralization of primary adipose-derived stem cells and a bone marrow stromal cell line. Int J Food Sci Nut. 2013;64:429-36.

25. Ducy P, Zhang R, Geoffroy V, Ridall AL, Karsenty G. Osf2/Cbfa1: A transcriptional activator of osteoblast differentiation. Cell. 1997;89:747-54

26. Nefussi JR, Boy-Lefèvre ML, Boulekbache H, Forest N. Mineralization in vitro of matrix formed by osteoblasts isolated by collagenase digestion. Differentiation. 1985;29:160-8.

27. Kern B, Shen J, Starbuck M, Karsenty G. Cbfa1 contributes to the osteoblastspecific expression of type I collagen genes. J Biol Chem. 2001;276:7101-7.

28. Vaes BLT, Ducy P, Sijbers AM, Hendriks JM, van Someren EP, de Jong NG, et al. Microarray analysis on Runx -2 deficient mouse embryos reveals novel Runx-2 functions and target genes during intramembranous and endochondral bone formation. Bone. 2006:39:724-38.

29. Moioli EK, Hong L, Mao JJ. Inhibition of osteogenic differentiation of human mesenchymal stem cells. Wound Repair Regen. 2007;15:413-21.

30. Bruder SP, Jaiswal N, Ricalton NS. Mesenchymal stem cells in osteobiology and applied bone regeneration. Clin Orthop Relat Res. 1998;355S:S247-56.

31. Payushina OV, Domaratskaya El, Starostin VI. Mesenchymal stem cells: sources, phenotype, and differentiation potential. Cell Biol. 2006;33:2-18.

32. Marcondes FK, Bianchi FJ, Tanno AP. Determination of the estrous cycle phases of rats: some helpful considerations. Braz J Biol. 2002;62:609-14.

33. Valério P, Pereira MM, Goes AM, Leite MF. The effect of ionic products from bioactive glass dissolution on osteoblast proliferation and collagen production. Biomaterials. 2004;25:2941-8.

34. Ocarino NM, Boeloni JN, Goes AM, Silva JF, Marubayashi U, Serakides R. Osteogenic differentiation of mesenchymal stem cells from osteopenic rats subjected to physical activity with and without nitric oxide synthase inhibition. Nitric Oxide. 2008:19:320-5.

35. Boeloni JN, Ocarino NM, Melo AB, Silva JF, Castanheira P, Goes AM, et al. Dose-dependent effects of triiodothyronine on osteogenic differentiation of rat bone marrow mesenchymal stem cells. Horm Res. 2009;71:88-97.

36. Ocarino NM, Boeloni JN, Jorgetti V, Gomes DA, Goes AM, Serakides R. Intra-bone marrow injection of mesenchymal stem cells improves the femur bone mass of osteoporotic female rats. Connect Tissue Res. 2010;51:426-33.

37. Sampaio IBM. Estatística aplicada à experimentação animal. Belo Horizonte: FEP/MVZ; 1998

38. Kamagata-Kiyoura Y, Ohta M, Cheuk G, Yazdani M, Saltzman MJ, Nakamoto T. Combined effects of caffeine and prostaglandin E2 on the proliferation of osteoblast-like cells. J Periodontol. 1999;70:283-8.

39. Barone LM, Tassinari MS, Bortell R, Owen TA, Zerogian J, Gagne K, et al. Inhibition of induce endochondral bone development in caffeine-treated rats. J Cel Bioch. 1993:52:171-82.

40. Reis AMS. Efeitos in vivo e in vitro da cafeína sobre o tecido cartilaginoso de ratos em crescimento. Dissertação (Mestrado em Patologia Animal), Escola de Veterinária, Universidade Federal de Minas Gerais; 2012.

41. Nefussi JR, Brami G, Modrowski D, Oboeuf M, Forest N. Sequential expression of bone matrix proteins during rat calvaria osteoblast differentiation and bone nodule formation in vitro. J Histochem Cytochem. 1997:45:493-503.

42. Addison WN, McKee MD. ASARM mineralization hypothesis: a bridge to progress. J Bone Miner Res. 2010;25:1191-2.

43. Zhou Y, Guan XX, Zhu ZL, Guo J, Huang YC, Hou WW, et al. Caffeine inhibits the viability and osteogenic differentiation of rat bone marrow-derived mesenchymal stromal cells. J Pharmacol. 2010;161:1542-52.

44. Sauvageau G, Iscove NN, Humphries RK. In vitro and in vivo expansion of hematopoietic stem cells. Oncogene. 2004;23:7223-32. 
45. Badilho AT, Flake AW. The regulatory role of stromal microenvironments in fetal hematopoietic ontogeny. Stem Cell Rev. 2006;2:241-6.

46. Sugiyama D, Inoue-Yokoo T, Fraser ST, Kulkeaw K, Mizuochi C, Horio Y. Embryonic regulation of the mouse hematopoietic niche. Sci World J. 2011;11:1770-80.

47. Tsai MT, Li WJ, Tuan RS, Chang WH. Modulation of osteogenesis in human mesenchymal stem cells by specific pulsed electromagnetic field stimulation. J Orthop Res. 2009;27:1169-74.

48. Granéli $C$, Thorfve A, Ruetschi U, Brisby $H$, Thomsen $P$, Lindahl A, et al. Novel markers of osteogenic and adipogenic differentiation of human bone marrow stromal cells identified using a quantitative proteomics approach. Stem Cell Res. 2014;12:153-65.

49. Birket MJ, Orr AL, Gerencser AA, Madden DT, Vitelli C, Swistowski A, et al. A reduction in ATP demand and mitochondrial activity with neural differentiation of human embryonic stem cells. J Cell Sci. 2011;124:348-58.

50. Xu X, Duan S, Yi F, Ocampo A, Liu G. Mitochondrial regulation in pluripotent stem cells. Cell Metab. 2013;18:1-8.

51. Aronow MA, Gertenfeld LC, Owen TA, Tassinari MS, Stein GS, Lian JB. Factors that promote progressive development of the osteoblast phenotype in cultured fetal rat calvaria cells. J Cell Physiol. 1990;143:213-21.

52. Cowles EA, Derome ME, Pastizzo G, Brailey LL, Gronowicz GA. Mineralization and the expression of matrix proteins during in vivo bone development. Calcif Tissue Int. 1998;1998(62):74-82.

53. Bellows CG, Ciaccia A, Heersche JNM. Osteoprogenitor cells in cell populations derived from mouse and rat calvaria differ in their response to corticosterone, cortisol, and cortisone. Bone. 1998;23:119-25.

54. Shih YRV, Chen CN, Tsai SW, Wang YJ, Lee OK. Growth of mesenchymal stem cells on electrospun type I collagen nanofibers. Stem Cells. 2006:24:2391-7.

55. Abarca-buis RF, Cázares DG, Monroy JC. Mecanismos moleculares que controlan el desarrollo de la extremidad de los vertebrados. Rev Esp Cienc Quím Biol. 2006;9:78-89.

56. Lorda-diez Cl, Montero JA, Mendoza MJD, Garcia-Porrero JA, Hurle JM. Defining the earliest transcriptional steps of chondrogenic progenitor specification during the formation of the digits in the embryonic limbs. Plos One. 2011;6:e24546.

57. Ueta C, Iwamoto M, Kanatani N, Yoshida C, Liu Y, Enomoto-Iwamoto M, et al. Skeletal malformations caused by overexpression of cbfa1 or its dominant negative form in chondrocytes. J Cell Biol. 2001;153:87-99.

58. Costa MA, Barbosa A, Neto E, Sá-e-Sousa A, Freitas R, Neves JM, et al. On the role of subtype selective adenosine receptor agonists during proliferation and osteogenic differentiation of human primary bone marrow stromal cells. J Cell Physiol. 2011;226:1353-66.

59. Ribeiro JA, Sebastião AM. Caffeine and adenosine. J Alzheimers Dise 2010;20:S3-15.

60. Taylor AF. Osteoblastic glutamate receptor function regulates bone formation and resorption. J Musculoskelet Neuronal Interact. 2002;2:285-90.

61. Solinas M, Ferré S, You ZB, KarcZ-Kubicha M, Popoli P, Goldberg SR. Caffeine induces dopamine and glutamate release in the shell of the nucleus accumbens. J Neurosci. 2002;22:6321-4.

62. Ma Y, Nyman JS, Tao H, Moss HH, Yang X, Elefteriou F. B2-Adrenergic recepto signaling in osteoblasts contributes to the catabolic effect of glucocorticoids on bone. Endocrinology. 2011;152:1412-22.

63. Salahdeen HM, Alada AR. Role of adrenergic receptors in the caffeine-induced increase in glucose uptake by the canine hindlimb. Niger J Physiol Sci. 2009:24:141-7.

64. Föcking M, Schmiegelt D, Trapp T. Caffeine-mediated enhancement of glucocorticoid receptor activity in human osteoblastic cells. Biochem Biophys Res Commun. 2005:337:435-9.

65. Tam J, Trembovler V, Di Marzo V, Petrosino S, Leo G, Alexandrovich A, et al. The cannabinoid $C B 1$ receptor regulates bone formation by modulating adrenergic signaling. FASEB J. 2008;22:285-94.

66. Rossi S, De Chiara V, Musella A, Mataluni G, Sacchetti L, Siracusano A, et al. Caffeine drinking potentiates cannabinoid transmission in the striatum: interaction with stress effects. Neuropharmacology. 2009;56:590-7.

67. Ferron M, Wei J, Yoshizawa T, Del Fattore A, DePinho RA, Teti A, et al. Insulin signaling in osteoblasts integrates bone remodeling and energy metabolism. Cell. 2010;142:296-308.

68. Egawa T, Tsuda S, Ma X, Hamada T, Hayashi T. Caffeine modulates phosphorylation of insulin receptor substrate-1 and impairs insulin signal transduction in rat skeletal muscle. J Appl Physiol. 2011;111:1629-36.
69. Wiren KM, Chapman Evans A, Zhang XW. Osteoblast differentiation influences androgen and estrogen receptor-alpha and -beta expression. J Endocrinol. 2002;175:683-94.

70. Palacios N, Weisskopf M, Simon K, Gao X, Schwarzschild M, Ascherio A. Polymorphisms of caffeine metabolism and estrogen receptor genes and risk of Parkinson's disease in men and women. Parkinsonism Relat Disord. 2010;16:370-5

71. Sarobo C, Lacorte LM, Martins M, Rinaldi JC, Moroz A, Scarano WR, et al. Chronic caffeine intake increases androgenic stimuli, epithelial cell proliferation and hyperplasia in rat ventral prostate. Int J Exp Pathol. 2012;93:429-37.

72. Wang Y, Zhu J, DeLuca HF. Identification of the vitamin D receptor in osteoblasts and chondrocytes but not osteoclasts in mouse bone. J Bone Miner Res. 2014;29:685-92.

\section{Submit your next manuscript to BioMed Central and take full advantage of:}

- Convenient online submission

- Thorough peer review

- No space constraints or color figure charges

- Immediate publication on acceptance

- Inclusion in PubMed, CAS, Scopus and Google Scholar

- Research which is freely available for redistribution 